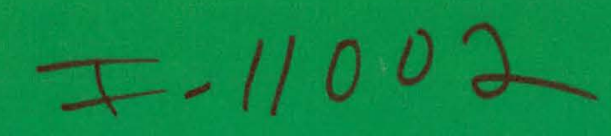

Dr. $1729-9$

DP -1658

\title{
TWO-STAGE PRECIPITATION OF NEPTUNIUM (IV) OXALATE
}

DAVID W. LUERKENS

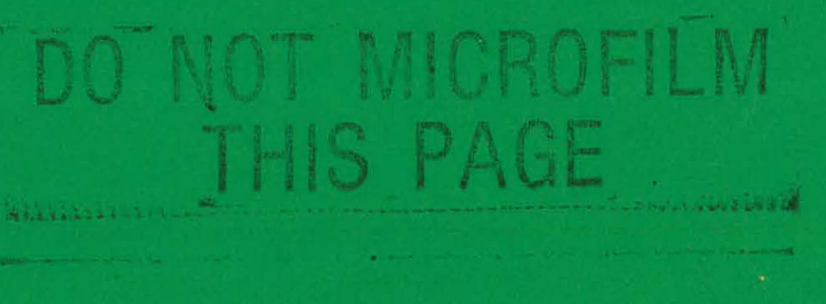

4

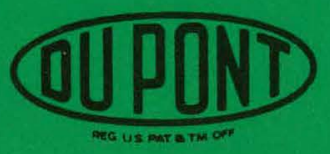

E. I. du Pont de Nemours \& Co. Savannah River Laboratory Aiken, SC 29808

PREPARED FOR THE U. S. DEPARTMENT OF ENERGY UNDER CONTRACT DE-ACO9-76SRO0001 


\section{DISCLAIMER}

This report was prepared as an account of work sponsored by an agency of the United States Government. Neither the United States Government nor any agency Thereof, nor any of their employees, makes any warranty, express or implied, or assumes any legal liability or responsibility for the accuracy, completeness, or usefulness of any information, apparatus, product, or process disclosed, or represents that its use would not infringe privately owned rights. Reference herein to any specific commercial product, process, or service by trade name, trademark, manufacturer, or otherwise does not necessarily constitute or imply its endorsement, recommendation, or favoring by the United States Government or any agency thereof. The views and opinions of authors expressed herein do not necessarily state or reflect those of the United States Government or any agency thereof. 


\section{DISCLAIMER}

Portions of this document may be illegible in electronic image products. Images are produced from the best available original document. 


\section{The following pages are an exact representation of what is in the original document folder.}




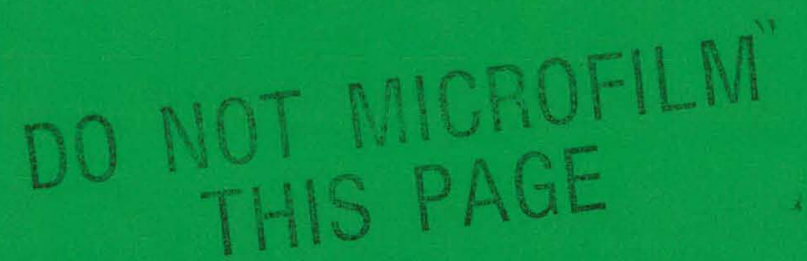

This report was prepared by E. I. du Pont de Nemours and Company (Du Pont) for the United States Department of Energy under Contract DE-AC09-76SR00001 and is an account of work performed under that Contract. Neither the United States, the United States Department of Energy nor Du Pont, nor any of their employees, makes any warranty, express or implied, or assumes any legal liability or responsibility for the accuracy, completeness, or usefulness of any information, apparatus, product, or process disclosed herein, or represents that its use will not infringe privately owned rights. Reference herein to any specific commerical product, process, or service by trade name, mark, manufacturer, or otherwise does not necessarily constitute or imply endorsement, recommendation, or favoring of same by Du Pont or by the United States Government or any agency thereof. The views and opinions of authors expressed herein do not necessarily state or reflect those of the United States Government or any agency thereof.

Printed in the United States of America

Available from

National Technical Information Service

U. S. Department of Commerce

5285 Port Royal Road

Springfield, Virginia 22161

Price: Printed Copy A03; Microfiche A01 
Distribution Category UC- 4

\section{TWO-STAGE PRECIPITATION OF NEPTUNIUM (IV) OXALATE}

DP --1658

DE83 017052
DAVID W. LUERKENS

Approved by

Harry D. Harmon, Research Manager

Actinide Technolugy Division

\section{DISCLAIMER}

This report was prepared as an account of work sponsored by an agency of the United States Government. Neither the United States Government nor any agency thercof, nor any of their bility for the accuracy, completencss, or implied, or assumes any legal liability or responsiprocess disclosed, or represents that its use would of any information, apparatus, product, or ence herein to any specific commercial product, manufacturer, or otherwise does not necessarily conss, or service by trade name, trademark, mendation, or favoring by the United Staterily constitute or imply its endorsement, recomand opinions of authors expressed herein United States Government or any agency thereof.

Publication Date: July 1983

\section{E. I. du Pont de Namours $8 \mathrm{Co}$. Savannah River Laboratory Aiken, SC 29808}

PREPARED FOR THE U. S. DEPARTMENT OF ENERGY UNDER CONTRACT DE-AC09-76SR00001 


\section{ABSTRACT}

Neptunium (IV) oxalate was precipitated using a two-stage precipitation system. A series of precipitation experiments was used to identify the significant process variables affecting precipitate characteristics. Process variables tested were input concentrations, solubility conditions in the first stage precipitator, precipitation temperatures, and residence time in the first stage precipitator. A procedure has been demonstrated that produces neptunium (IV) oxalate particles that filter well and readily calcine to the oxide. 


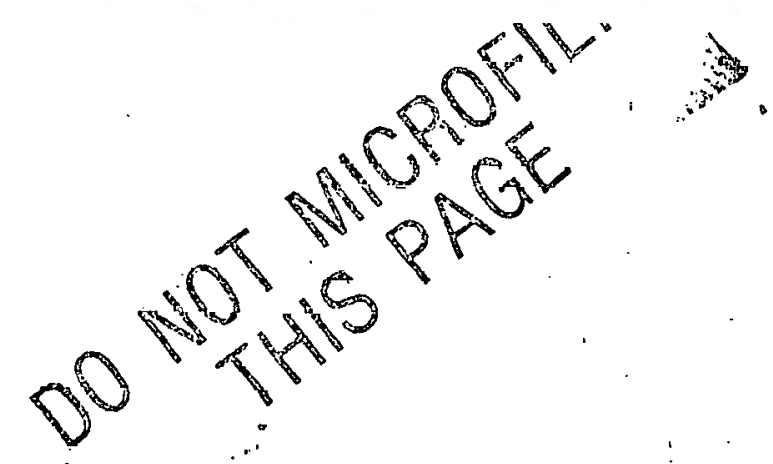

$-4-$ 


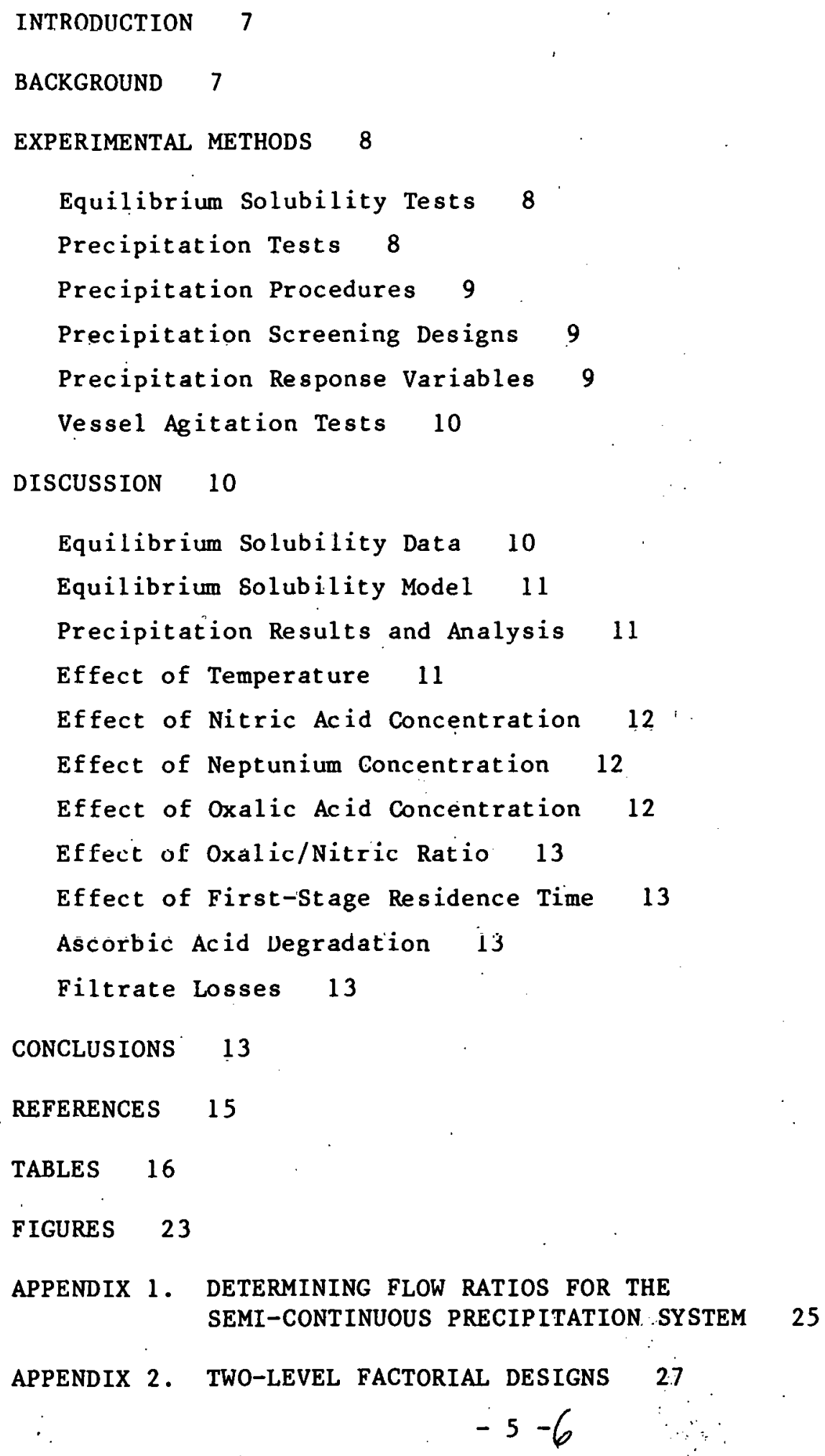




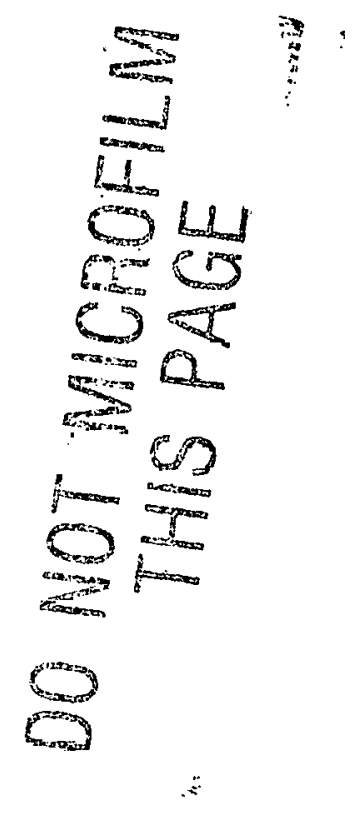

$-6-$ 


\section{INTRODUCTION}

The Savannah River Plant recovers neptunium-237 by precipitation as neptunium (IV) oxalate. It is then calcined to neptunium oxide, mixed. with powdered aluminum, and pressed into billets for fabrication into reactor targets. The targets are irradiated to produce plutonium-238 for use as heat sources in radioisotopic generators.

Neptunium oxide powder must be produced with optimum characteristics for blending with aluminum powder for billet fabrication. Characteristics of the oxide depend on the precursor neptunium oxalate. New neptunium facilities, now under construction, will use a new two-stage precipitation system to precipitate neptunium (IV) oxalate. The primary objectives of the new system are to provide product versatility and to maintain consistent control over product characteristics.

This report summarizes laboratory development work for neptunium (IV) oxalate precipitation using a two-stage precipitation system.

\section{BACRGROURD}

Different solution conditions during precipitation influence particle characteristics of the precipitated material. These particle characteristics determine the performance of the precipitation process. For example, in most precipitation processes, conditions of high supersaturation promote crystal nucleation whereas conditions of low supersaturation promote crystal growth. Precipitation conditions which predominantly favor nucleation can result in excess "fines" generation which can plug filter boats and increase product filtration times. Precipitation conditions which predominantly favor crystal growth can result in "plating" on interior surfaces. Plated material increases personnel radiation exposure.

Successful precipitation processes ultimately optimize the conditions of supersaturation to provide sufficient nuclei which $c$ an be grown to larger particles while avoiding excess nucleation 
(fines) or growth (plating) condition. In general, selection of these optimum precipitation conditions depends in part on precipitation equipment, feed stream compositions, precipitation solubility conditions, precipitation kinetic relations, and mixing specifications.

\section{EXPERIMENTAL METHODS}

\section{Equilibrium Solubility Tests}

Pure solutions of neptunium (IV) in dilute nitric acid required for solubility and precipitation studies were prepared by dissolving neptunium oxide and purifying by anion exchange.

The equilibrium solubility of neptunium (IV) oxalate in nitric/oxalic acid solutions was determined 1 ar $22^{\circ} \mathrm{C}, 49^{\circ} \mathrm{C}$, and $60^{\circ} \mathrm{C}$. Neptunium (IV) oxalate was precipitated from solutions of known concentrations of oxalic and nitric acids. The nitric/oxalic acid solutions represented a wide range of free oxalate ion concentration. After equilibration, the solutions were analyzed to determine the solubility of neptunium (IV) oxalate. Neptunium analyses were performed by standard alpha counting techniques.

\section{Precipitation Tests}

All precipitations were performed using a small scale twostage precipitation system (Figure 2). A series of precipitation experiments was used to identify the significant process variables affecting precipitate characteristics. Response variables in these experiments were the neptunium oxalate and oxide particle size distributions, plating in the precipitators, and extent of precipitation in the first stage precipitator. The major process variables of interest were:

\section{Process Variable}

Neptunium feed concentration to

the first stage precipitator.

Nitric acid concentration

In the neprunium feed.

Oxalic acid concentration to the first stage precipitator.

Residence time in the first stage precipitator.

$$
\begin{aligned}
& \frac{\text { Range }}{10-20 \mathrm{~g} / \mathrm{L}} \\
& 1-3.5 \mathrm{M} \\
& 0.45-0.9 \mathrm{M} \\
& 2-10 \mathrm{~min}
\end{aligned}
$$


Process Variable

Temperature in the first stage precipitator.

Temperature in the second stage precipitator.

Oxalic/nitric ratio (i.e. Rs value)
Range

$$
\begin{aligned}
& 22-60^{\circ} \mathrm{C} \\
& 22-60^{\circ} \mathrm{C} \\
& \text { oxalic - oxalic } \\
& \text { lean rich } \\
& \text { (cation) (anion) }
\end{aligned}
$$

Experimental flow rates for the two-stage precipitation system were determined (Appendix 1) as functions of the process variables. A two-level factorial screening design 2 was used to set up process parameters for the precipitation experiments.

\section{Precipitation Procedures}

Neptunium (IV) oxalate was precipitated from neptunium (IV) nitrate solutions containing 10 to 25 grams of neptunium per liter in 1.0 to $3.5 \mathrm{M}$ nitric acid. The neptunium feed solution contained $0.05 \mathrm{M}$ hydrazine to stabilize the neptunium (IV) valence state 3,4 . Ascorbic acid was added to the neptunium feed before precipitation to reduce any neptunium (V) to neptunium (IV). The presence of neptunium ( $V$ ) results in higher losses to the filtrate. The neptunium oxalate precipitations were on a 2.0 to 5.0 gram scale.

\section{Preçipitation Screening Designs}

The main use of a screening design is to efficiently identify the few really important variables among a larger number of possib.le variables with a minimum number of experiments. A detailed explanation and analysis 2,5 of the two-level factorial experimental designs may, be found in Appendix 2. Table 1 shows the experimental screening design 2 used for the neptunium (IV) oxalate precipitations.

\section{Precipitation Response Variables}

The particle size distributions of neptunium oxalate and neptunium oxide were used to evaluate the quality of precipitates formed under a given set of conditions. Measures used to evaluate quality were: mode, median, volume percent of particles less than 5 microns, and volume percent of particles greater than 20 microns. Particle size distributions were determined by Coulter Counter analysis. 
The mode of the particle size distribution was used as a measure of precipitate quality because it is not influenced by extreme observations. This mode is simply the size that occurs most frequently. The median is the midpoint of the particle size distribution and is somewhat sensitive to extreme values. The mean is very sensitive to extreme values. The volume percentage of particles less than 5 micron was used to evaluate the formation of fines. This measure is useful regarding filtration characteristics of the oxalate.

The extent of plating in the precipitators was simply noted as none, light, or heavy. This was a qualitative observation.

\section{Vessel Agitation Tests}

A series of agitation tests were performed on the small scale two-stage precipitation system. The tests involved observation of $\mathrm{NaOH} / \mathrm{HNO}_{3}$ neutralization reactions using colored indicators. The rate of color change in the precipitation system is limited by mixing kinetics and not neutralization kinetics. The neutralization reactions are very fast. Bulk mixing times of less than 5 seconds were typical in the first and second stage precipitation vessels.

Three-bladed marine type impellers (down pumping) were used in both vessels. Tip speeds of the agitators in the first and second stage precipitation vessels were 4.4 and 5.0 feet/sec respectively, per recommendation from previous neptunium (IV) oxalate precipitation work. 6 One-inch and three-inch-diameter impellers were used in the first and second stage precipitation vessels, respectively.

\section{DISCUSSION}

\section{Equilibrium Solubility Data}

Equilibrium eolubility data have been previnusly published.1 The data show that neptunium (IV) oxalate solubility is a function of the free oxalate ion concentration (1.e., denoted $R_{S}$ ). Equilibria between neptunium (IV) oxalate complexes account for the varylng sulubilily. Fuus uxalate complexes have bcen reportcd 6-9 in the literature. Minimum snluhility results when the formation of the highly insoluble dioxalate complex is favored. Increased solubility restilts from the formation of cationic or anionic complexes as the free oxalate ion concentration varies from optimum values. 


\section{Equilibrium Solubility Model}

Complex equilibria were used to develop a mathematical mode 1 of the equilibrium solubility of neptunium (IV) oxalate as a function of free oxalate ion concentration (denoted by $R_{S}$ ). Figure 1 shows the predicted equilibrium solubility curves at each temperature.

Using the solubility model, the contribution ot the overall equilibrium solubility from the formation of a particular complex species can be associated with a region of the solubility curve. For example, the cationic complex predominates in the region of small values of $R_{S}$ (i.e., $R_{S}<0.01$ ). This region of the solubility curve is known as the oxalic-lean region. 10 As $R_{S}$ increases (i.e., $0.01<\mathrm{R}_{\mathrm{s}}<0.2$ ) the solubility minimum is reached when the formation of the highly insoluble dioxalate complex is favored. The equilibria involving the formation of the neutral complex predominates in this region. However, as $R_{S}$ further increases (i.e., $R_{S}>0.2$ ), the solubility increases because of the formation of the highly soluble anionic complex. This region of the solubility curve is known as the oxalic-rich region. 10

In the region of high free oxalate ion concentration, the solubility curve at $60^{\circ} \mathrm{C}$ intersects and falls below the solubility curve at $45^{\circ} \mathrm{C}$. This behavior suggests high temperature instability of the anionic complex, $\mathrm{Np}\left(\mathrm{C}_{2} \mathrm{O}_{4}\right) 3^{2-}$.

Using the mathematical model of the equilibrium solubility it can be shown that the solubility minimum shifts to higher free oxalate ion concentrations as the temperature increases.

\section{Precipitation Results and Analysis}

Table 1 shows the experimental screening design ${ }^{2}$ used for the precipitations. Table 2 shows the actual flow rates, extent of conversion, and filtrate losses from the precipitation experiments. Particle size distribution data are given in Tables 3 and 4. Analysis of these data follow standard statistical analys is 2,5 of two-level fractional factorial designs and is shown in Tables 5 through 7 .

\section{Effect of Temperature}

Table 3 shows data obtained in the neptunium (IV) oxalate precipitation experiments. The particle size is strongly influenced by the temperature during precipitation. Larger oxalate particles 
were obtained when both precipitators were at the higher temperature. The higher precipitation temperatures provided better particle growth and reduced the amount of fines (i.e., the percent of material less than 5.0 microns). This effect is shown in Table 6." Particle sizes were routinely between 25 and 40 microns.

When both precipitators were at room temperature, the oxalate particle sizes were typically less than 16 microns.

When the precipitators were operated at different temperatures the results varied. When the first stage precipitator was at $60^{\circ} \mathrm{C}$ and the second stage at ambient, the oxalate particle sizes varied between 15 and 25 microns. When the first stage precipitator was: at ambient and the second stage at $60^{\circ} \mathrm{C}$ the oxalate particle sizes varied between 20 and 30 microns.

The rate of reduction of neptunium (V) to neptunium (IV) increases at higher temperatures. ${ }^{4}$

\section{Effect of Nitric Acid Concentration}

Neptunium (IV) oxalate particle size decreases with high nitric acid concentration in the neptunium (IV) feed stream. This effect is statistically significant as shown in Table 5. The nitric acid concentration ranged from 1.0 to $3.5 \mathrm{M}$ in these tests:

A lower limil of $1.5 \mathrm{M}$ nilric acid in the meplunium feed is recommended to prevent precipitation of ascorbic acid degradation product in the feed. The rate of reduction of neptunium (V) to neptunium (IV) increases with increasing nitric acid concentration. 6

\section{Effect of Neptunium Concentration}

Precipitation of neptunium (IV) oxalate from feed solutions containing 10 to $25 \mathrm{~g} / \mathrm{L}$ neptunium produced low waste losses and ... slurries that filtered well. "The overall effect of neptunium" concentration on particle size is not statistically significant.

\section{Effect of Oxalic Acid Concentration}

Oxalic acid concentration in the feed streams was varied between 0.45 and $0.9 \mathrm{M}$. Plating observed in the first stage precipitator decreased with higher feed concentrations of oxalic acid. This effect was statistically significant as shown in Table 7 . 


\section{Bffect of Oxalic/Nitric Ratio}

Large particles can be produced from precipitation conditions on both sides of the solubility minimum (i.e., cationic vs. anionic). However, cationic precipitation conditions, in general; produce significantly higher throughputs and lower waste volumes for a given design. Anionic precipitation conditions significantly reduced the rate "of precipitation in the first stage precipitatior by forming strong oxalate complexes with neptunium (Table 7).

\section{Effect of First-Stage Residence Time}

The effect of residence time in the first stage precipitator on particle size was not statistically significant in these studies. The range of first stage residence times was 2.0 to 8.0 minutes.

\section{Ascorbic Acid Degradation}

Excessive degradation of ascorbic acid was observed during the neptunium valence adjustment from neptunium (V) to neptunium (IV) at high temperatures. The ascorbic acid degradation product precipitated in the feed tanks. However, the sludge which formed was soluble in 3.0 to $4.0 \mathrm{M}$ nitric acid.

\section{Filtrate LoBses}

Table 2 shows filtrate losses for each precipitation test. Relatively higher filtrate losses were encountered for anionic precipitation conditions. Since total precipitation and digestion times were held constant, the higher filtrate losses are probably the result of a slow rate of dissociation of the anionic complex. Equilibrium solubility measurements show that filtrate losses of less than $10 \mathrm{mg} / \mathrm{L}$ would be expected if equilibrium was attained. Total precipitation time was one hour with 15 minutes digestion times.

\section{CONCLUSIONS}

The particle size of the neptunium (IV) oxalate precipitates is very sensitive to precipitation temperatures and concentrations of oxalic and nitric acids during precipitation. In general, larger particles were produced with precipitation temperatures in both vessels at $60^{\circ} \mathrm{C}$. Anionic precipitation conditions reduced the 
rate of precipitation in the first stage precipitator and contributed to higher losses in the filtrates. Both effects are due to the formation of strong oxalate complexes. with neptunium. The nitric acid concentration in the neptunium (IV) nitrate. feed solution should be at least $1.5 \mathrm{M}$ to prevent precipitation of the ascorbic acid degradation product in the feed tanks. The effect of residence time on particle size was not statistically significant in these studies. The recommended conditions for optimum operation. of the two-stage precipitation system are summarized below:

1. The temperature in the first and second stage precipitators should be 50 to $60^{\circ} \mathrm{C}$ during precipitation.

2. Filtration temperature should be at ambient.

3. The cuncentiation of nitric acid in the actinide feed should he in the range of 1.5 to $3.0 \mathrm{M}$.

4. The concentration of oxalic acid used for precipitation should be $-1.0 \mathrm{M}$.

5. The oxalic acid to nitric acid ratio in the first stage precipitator should be less than 0.005 during precipitation.

6. The oxalic acid to nitric acid ratio in the second stage precipitator should be in the range of 0.01 to 0.3 to minimize solubility losses. 
1. D. W. Luerkens, Neptunium (IV) Oxalate Solubility. USDOE Report DP-1655, E. I. du Pont de Nemours \& Co., Savannah River Laboratory, Aiken, SC (July 1983).

2. D. W. Marquardt, B. S. Brown, K. A. Chatto, and R. D. Snee. Stategy of Experimentation. Engineering Department, E. I. du. Pont de Nemours and Co., Inc., Wilmington, Delaware (March 1970, Revised 1977).

3. G. A. Burney. Separation of Neptunium and Plutonium by Anion Exchange. USAEC Report DP-689, E. I. du Pont de Nemours \& Co., Savannah River Laboratory, Aiken, SC (April 1962).

4. D. G. Karraker. Hydrazine Reduction of $\mathrm{Np}(\mathrm{V})$ and $\mathrm{Pu}(\mathrm{IV})$. USDOE Report DP-1601, E. I.' du Pont de Nemours \& Co., Savannah River Laboratory, Aiken, SC (November 1981).

5. M. G. Natrella. Experimental Statistics." Handbook 91, National Bureau of Standards, United States Department of Commerce, Library of Congress Catalog Number 63-60072.

6. J. A. Porter. Precipitation of Neptunium Oxalate and Calcination to Neptunium Oxide. USAEC Report DP-591, E. I. du Pont de Nemours \& Co., Savannah River Laboratory, Aiken, SC (July 1961).

7. P. I. Kondratov and A. D. Gel'man. Radiokhimiya 2, 315 (1960).

8. V. A. Milkailov. Analytical Chemistry of Neptunium. Halsted Press, a Division of John Wiley and Sons Inc., New York.

9. Gel'man, et al. "Complex Compounds of the Transuranides." Academy of Sciences of the USSR, Israel Program for Scientific Translation, Jerusalem (1967).

10. P. R. Monson, Jr. and R. Hall. Thorium Oxalate Solubility and Morphology. USDOE Report DP-1576, E. I. du Pont de Nemours $\&$ Co., Savannah River Laboratory, Aiken, SC (October 1981). 


\section{TABLE 1}

Precipitation Screening Design

\begin{tabular}{|c|c|c|c|c|c|c|c|c|}
\hline Run \# & $\begin{array}{l}\text { Temp } P 1 \\
\left({ }^{\circ} \mathrm{C}\right)\end{array}$ & $\begin{array}{l}{\left[N_{p}\right]_{f}} \\
(g / L)\end{array}$ & $\begin{array}{l}{\left[\mathrm{HNO}_{3}\right]} \\
(\mathrm{M})\end{array}$ & $\begin{array}{l}\text { Res. } \\
\text { (Min) }\end{array}$ & Time & $\mathbf{R}_{\mathbf{s}}$ & $\begin{array}{l}\text { Temp P2 } \\
\left({ }^{\circ} \mathrm{C}\right)\end{array}$ & $(\mathrm{M})^{\left[\mathrm{H}_{2} \mathrm{C}_{2} \mathrm{O}_{4}\right]_{f}}$ \\
\hline $\mathrm{R}-1$ & 22 & 10 & 3.5 & 2.0 & & anion & 60 & 0.9 \\
\hline $\mathrm{R}-2$ & 22 & 20 & $3.5^{\circ}$ & 7.0 & & anion & 22 & 0.45 \\
\hline$R-3$ & 60 & 20 & 3.5 & 2.0 & & cation & 22 & 0.9 \\
\hline$R-4$ & $60:$ & 10 & 3.5 & 2.0 & & anion & 22 & 0.45 \\
\hline$R-5$ & 60 & 20 & 1.0 & 7.0 & & cation & 22 & 0.45 \\
\hline$R-6$ & 22 & 10 & 1.0 & 2.0 & & cation & 22 & 0.45 \\
\hline $\mathrm{R}-7$ & 60 & 10 & 1.0 & 2.0 & & cation & $6 n$ & $n .9$ \\
\hline$R-8$ & 22 & 10 & 3.5 & 7.0 & : & cation & 22 & 0.9 \\
\hline$R-9$ & 60 & 20 & 1.0 & 2.0 & & anion & 60 & 0.45 \\
\hline$R-10$ & 22 & 10 & 1.0 & 7.0 & & anion & bu & 0.45 \\
\hline $\mathrm{R}-11$ & 22 & 20 & 1.0 & 2.0 & : & anion & 22 & 0.9 \\
\hline $\mathrm{R}-12$ & 22 & 20 & 1.0 & 7.0 & & cation & 60 & 0.9 \\
\hline$R-13$ & 60 & 10 & 3.5 & 7.0 & & cation & 60 & 0.45 \\
\hline$R-14$ & 60 & 20 & 3.5 & 7.0 & & anion & 60 & 0.9 \\
\hline $\mathrm{R}-15$ & 22 & 20 & 3.5 & 2.0 & & cation & 60 & 0.45 \\
\hline$R-16$ & 60 & 10 & 1.0 & 7.0 & & anion & 22 & 0.9 \\
\hline
\end{tabular}




\section{TABLE 2}

\section{Precipitation Conditions - Screening Design Data}

\begin{tabular}{|c|c|c|c|c|c|c|c|}
\hline \multirow[b]{2}{*}{ Run 非 } & \multicolumn{3}{|c|}{ Flow Rates (mL/min) } & \multirow{2}{*}{\multicolumn{2}{|c|}{$\begin{array}{l}\mathrm{Np} \text { in overflow } \\
\text { (M) }\end{array}$}} & \multirow[b]{2}{*}{$\begin{array}{l}\text { Np Loss in } \\
\text { (mg/L) }\end{array}$} & \multirow[b]{2}{*}{ Filtrate } \\
\hline & $\begin{array}{l}\text { Actinide } \\
\text { Stream }\end{array}$ & $\begin{array}{l}\text { Oxalic } \\
\text { Stream }\end{array}$ & $\begin{array}{l}\text { Ad justment } \\
\text { Stream }\end{array}$ & & & & \\
\hline R-1 & 1.2 & 6.4 & 3.8 & 0.002 & . & $45.3 *$ & \\
\hline$R-2$ & 0.2 & 1.9 & 0.8 & 0.005 & . & $14.5 *$ & \\
\hline $\mathrm{R}-3$ & 6.3 & 1.1 & 1.9 & 0.004 & & 12.0 & \\
\hline $\mathrm{R}-4$ & 0.8 & 7.0 & 2.8 & 0.034 & & $80.2^{*}$ & \\
\hline$R-5$ & 1.5 & 0.5 . & 0.1 & 0.016 & & 19.0 & \\
\hline$R-6$ & 6.4 & 1.2 & 0.4 & 0.026 & & 11.4 & \\
\hline $\mathrm{R}-7$ & 6.9 & 0.7 & 0.2 & 0.034 & & 27.6 & \\
\hline $\mathrm{R}-8$ & 1.8 & 0.1 & 0.5 & 0.014 & & 14.7 & - \\
\hline$R-9$ & 1.9 & 5.3 & 2.3 & 0.019 & & $20.0 *$ & \\
\hline $\mathrm{R}-10$ & 0.6 & 1.7 & 0.7 & 0.002 & & $21.0 *$ & \\
\hline $\mathrm{R}-11$ & 2.5 & 4.5 & 3.3 & 0.037 & & $30.3^{*}$ & \\
\hline$R-12$ & 2.0 & 0.4 & 0.1 & 0.051 & & 7.4 & : \\
\hline $\mathrm{R}-13$ & 1.8 & 0.4 & 0.9 & 0.003 & & 8.4 & \\
\hline$R-14$ & 0.3 & 1.7 & 1.2 & 0.008 & . & $14.7^{*}$ & \\
\hline$R-15$ & 5.4 & 2.3 & 2.7 & 0.004 & & 11.6 & \\
\hline$R-16$ & 0.8 & 1.3 & 0.9 & 0.009 & & $53.7 *$ & \\
\hline
\end{tabular}

* Anionic precipitation conditions-higher losses due to slow dissociation of anionic complex. 
TABLE 3

Median and Mode for Neptunium Oxalates and: Oxides

\begin{tabular}{lllll} 
Run & $\begin{array}{l}\text { Oxalate } \\
\text { Mode } \\
(\mu \mathrm{m})\end{array}$ & $\begin{array}{l}\text { Oxide } \\
\text { Mode } \\
(\mu \mathrm{m})\end{array}$ & $\begin{array}{l}\text { Oxalate } \\
\text { Median } \\
(\mu \mathrm{m})\end{array}$ & $\begin{array}{l}\text { Oxide } \\
\text { Median } \\
(\mu \mathrm{m})\end{array}$ \\
\cline { 1 - 2 } $\mathrm{R}-1$ & 16.8 & 7.8 & 15.1 & 8.5 \\
$\mathrm{R}-2$ & 16.0 & 10.1 & 14.4 & 10.2 \\
$\mathrm{R}-3$ & 20.2 & 8.7 & 18.4 & 9.3 \\
$\mathrm{R}-4$ & 16.0 & 8.0 & 16.3 & 8.6 \\
$\mathrm{R}-5$ & 32.0 & 10.9 & 29.8 & 11.2 \\
$\mathrm{R}-6$ & 20.2 & 20.2 & 15.7 & 13.0 \\
$\mathrm{R}-7$ & 40.3 & 10.1 & 38.6 & 12.7 \\
$\mathrm{R}-8$ & 14.9 & 8.0 & 15.6 & 9.0 \\
$\mathrm{R}-9$ & 29.8 & 16.0 & 25.3 & 1.3 .5 \\
$\mathrm{R}-10$ & 32.0 & 8.0 & 30.1 & 9.2 \\
$\mathrm{R}-11$ & 16.0 & 9.4 & 15.8 & 8.9 \\
$\mathrm{R}-12$ & 20.2 & 12.7 & 20.8 & 11.8 \\
$\mathrm{R}-13$ & 25.4 & 12.7 & 28.1 & 12.7 \\
$\mathrm{R}-14$ & 20.2 & 8.0 & 20.8 & 11.9 \\
$\mathrm{R}-15$ & 16.0 & 6.3 & 16.8 & 7.9 \\
$\mathrm{R}-16$ & 12.7 & 6.3 & 13.7 & 8.1
\end{tabular}


TABLE 4

Particle Size Distribution Data for Neptunium Oxalate and Oxide

$\begin{array}{lllll}\text { Run } \# & \begin{array}{l}\text { Oxalate } \\ \%<5 \mu \mathrm{m}\end{array} & \begin{array}{l}\text { Oxide } \\ \%>30 \mu \mathrm{m}\end{array} & \begin{array}{l}\text { Oxalate } \\ \%<5 \mu \mathrm{m}\end{array} & \begin{array}{l}\text { Oxide } \\ \%>20 \mu \mathrm{m}\end{array} \\ \mathrm{R}-1 & 1.8 & 3.3 & 13.0 & 5.0 \\ \mathrm{R}-2 & 6.7 & 0.0 & 10.0 & 8.7 \\ \mathrm{R}-3 & 3.7 & 14.7 & 13.3 & 8.0 \\ \mathrm{R}-4 & 4.2 & .1 .0 & 18.0 & 2.2 \\ \mathrm{R}-5 & 0.5 & 44.3 & 14.0 & 12.7 \\ \mathrm{R}-6 & 5.7 & 4.0 & 17.0 & 27.0 \\ \mathrm{R}-7 & 1.3 & 61.3 & 10.7 & 28.7 \\ \mathrm{R}-8 & 2.2 & 3.0 & 11.0 & 8.0 \\ \mathrm{R}-9 & 2.3 & 29.7 & 11.0 & 20.7 \\ \mathrm{R}-10 & 2.7 & 46.7 & 12.3 & 12.0 \\ \mathrm{R}-11 & 1.7 & 3.0 & 12.0 & 1.7 \\ \mathrm{R}-12 & 1.7 & 12.0 & 11.0 & 12.7 \\ \mathrm{R}-13 & 2.5 & 36.0 & 6.7 & 17.7 \\ \mathrm{R}-14 & 1.2 & 27.7 & 14.3 & 4.3 \\ \mathrm{R}-15 & 1.7 & 12.7 & 16.0 & 2.8 \\ \mathrm{R}-16 & 3.3 & 4.3 & 16.3 & 5.7\end{array}$


TABLE 5

Analysis of the Mode and Median of the Particle Size Diotribution :

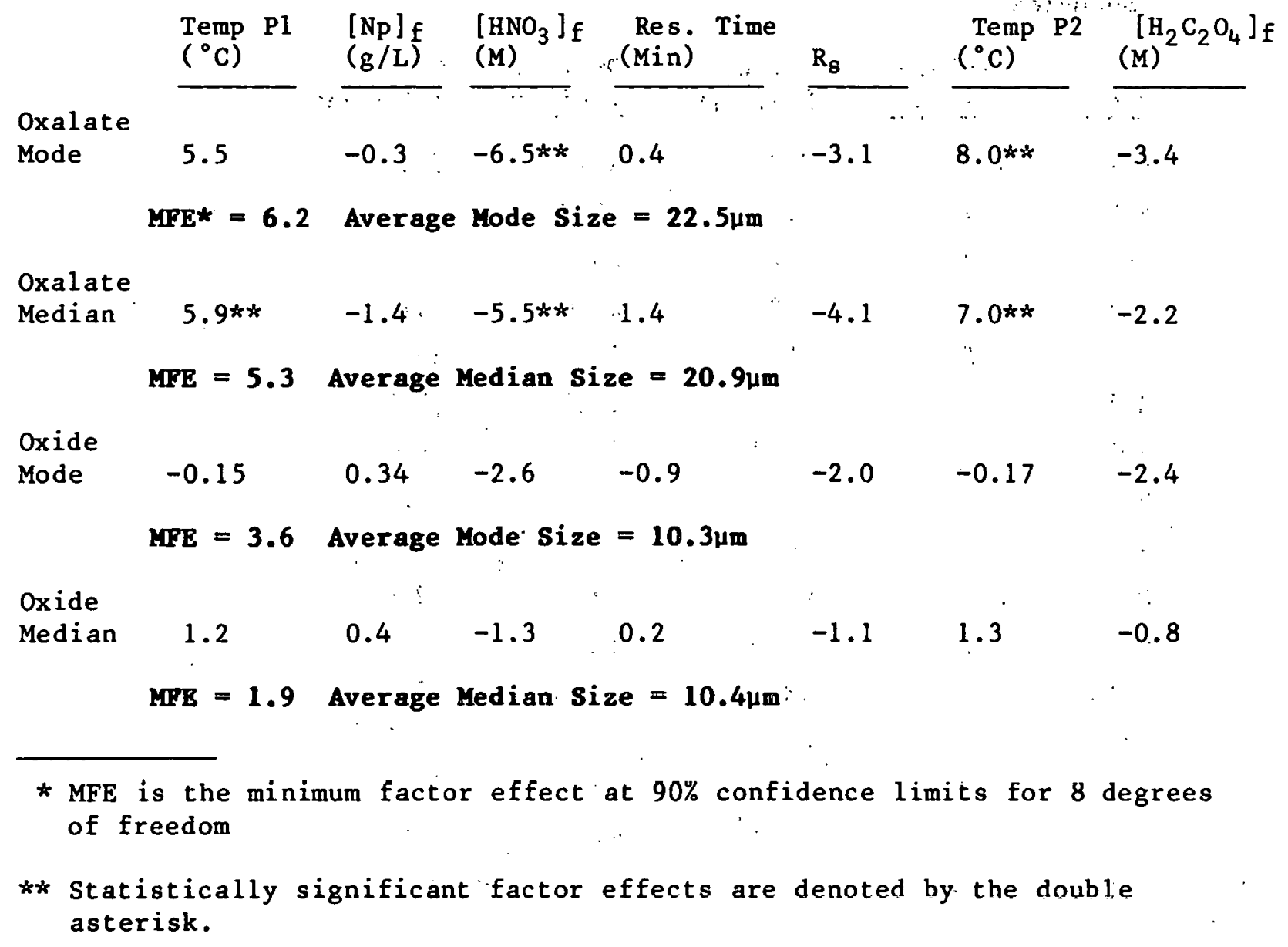


TABLE 6

Analysis of the Variables Affecting the Pormation of Pines

\begin{tabular}{|c|c|c|c|c|c|c|c|c|}
\hline $\begin{array}{l}\text { Temp } \\
\left({ }^{\circ} \mathrm{C}\right)\end{array}$ & PI & $\begin{array}{l}{\left[\mathrm{Np}_{\mathrm{f}}\right.} \\
(\mathrm{g} / \mathrm{L})\end{array}$ & $\begin{array}{l}{\left[\mathrm{HNO}_{3}\right]_{\mathrm{f}}} \\
(\mathrm{M})\end{array}$ & $\begin{array}{l}\text { Res. } \\
\text { (Min) }\end{array}$ & Time & $\mathbf{R}_{\mathbf{8}}$ & $\begin{array}{l}\text { Temp P2 } \\
\left({ }^{\circ} \mathrm{C}\right)\end{array}$ & $\underset{(M)}{\left[\mathrm{H}_{2} \mathrm{C}_{2} \mathrm{O}_{4}\right]}$ \\
\hline
\end{tabular}

Oxalate

$\%<5$.

$$
\begin{array}{cccc}
-0.7 & -0.5 & 0.6 & -0.2 \\
\text { MFE* }=1.56 & \text { Average } z<5 \mu \mathrm{m}=2.7 \%
\end{array}
$$

0.6

$-1.6 * * \quad-1.2$

$\%>30$

$\begin{array}{llll}16.7 * * & -1.9 & -13.3 & 5.6\end{array}$

5.6

$-9.0$

$19.3 * *: \quad:-5.7$

MFE $=13.6$, Average $\delta>30 \mu \mathrm{m}=19.0 \%$

Oxide

$\%<5$.

0.3

$$
-0.4 \quad-0.3 \quad-1.99
$$

0.9

$-2.1$

$-0.4$

MFE $=3.2$ Average $x<5 \mu \mathrm{m}=12.9 \%$

$\%>20$

$2.8 \quad-4.3 \quad-8.1^{* *} \quad-1.8$

$-7 \cdot 2 * *$

3.7

$-3.7$

MPE $=6.6$ Average $Z>20 \mu \mathrm{m}=11.1 \%$

* MFE is the minimum factor effect at $90 \%$ confidence 1 imits for 8 degrees of freedom

** Statistically significant factor effects are denoted by the double asterisk. 


\section{TABLE 7}

Significant Variables Affecting Plating in P1 and Reaction Rinetics:

\begin{tabular}{|c|c|c|c|c|c|c|c|}
\hline & $\begin{array}{l}\text { Temp PI } \\
\left({ }^{\circ} \mathrm{C}\right)\end{array}$ & $\begin{array}{l}{[\mathrm{Np}]_{\dot{f}}} \\
(\mathrm{~g} / \mathrm{L})\end{array}$ & $\underset{(\mathrm{M})}{\left[\mathrm{HNO}_{3}\right]_{\mathrm{f}}}$ & $\begin{array}{l}\text { Res. Time } \\
\text { (Min) }\end{array}$ & $\mathbf{R}_{S}$ & $\begin{array}{l}\text { Temp P2 } \\
\left({ }^{\circ} \mathrm{C}\right)\end{array}$ & $\underset{(\mathrm{M})}{\left[\mathrm{H}_{2} \mathrm{C}_{2} \mathrm{O}_{4}\right]_{f}}$ \\
\hline $\begin{array}{l}\text { Plating } \\
\text { in P1 }\end{array}$ & 0.0 & 0.3 & 0.0 & 0.0 & -0.3 & - & $-0.8 * *$ \\
\hline & $\mathrm{FE} *=0.4$ & Aver & respon & $e=0.4$ & & & \\
\hline $\begin{array}{l}\text { Reaction } \\
\text { Kinetic's }\end{array}$ & $-0.7 * *$ & $1.5 *$ & 0.8 & -1.4 & $-1.6 * *$ & 0.1 & -0.4 \\
\hline
\end{tabular}

* MFE is the minimum factor effect at $90 \%$ confidence 1 imits for 8 degrees of froodom

** Statistically significant factor effects are denoted by the double asterisk. 


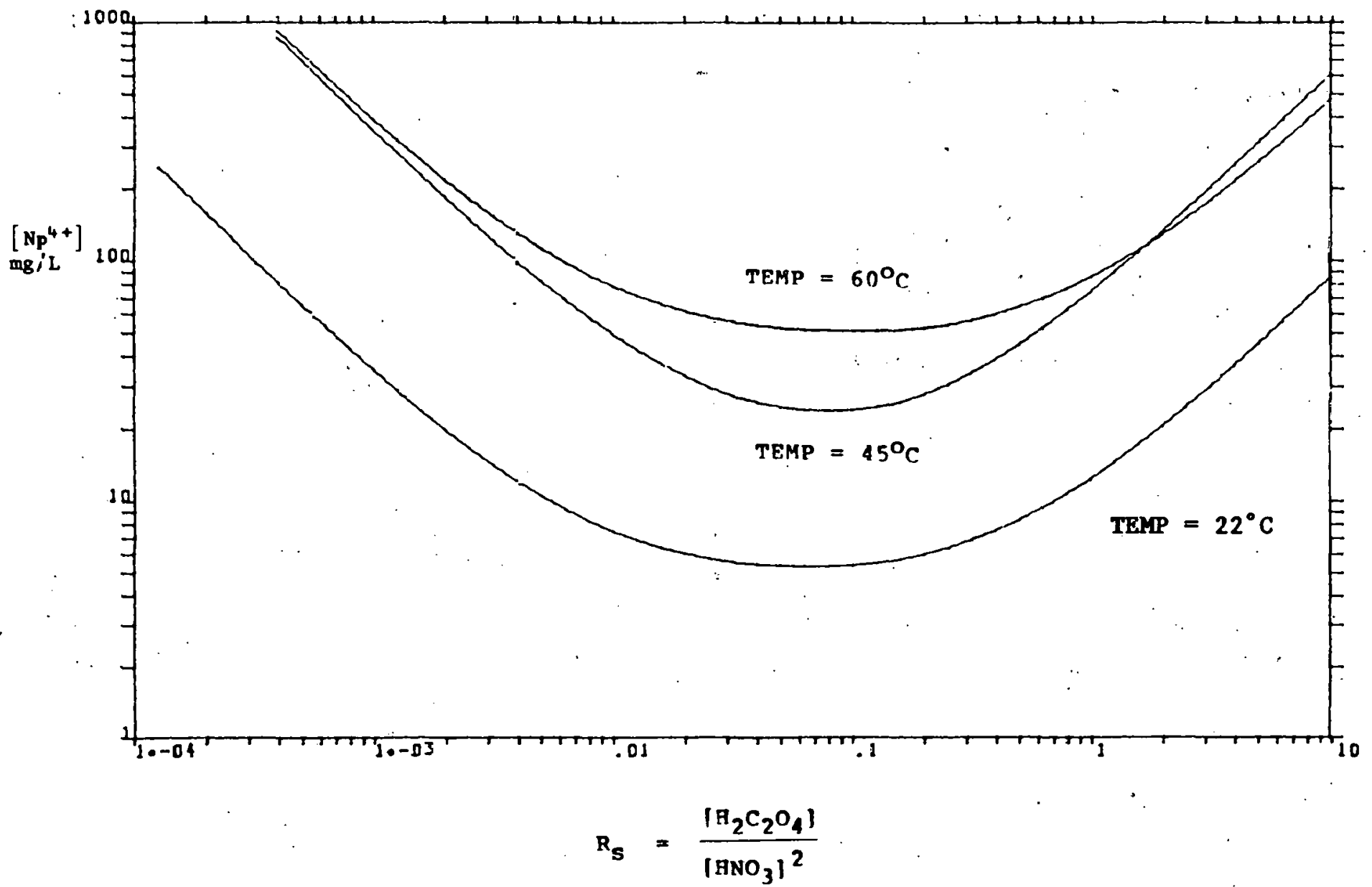

FIGURE 1. Predicted Solubility of Neptunium (IV) Oxalate Using the Least-Squares Solubility Model 


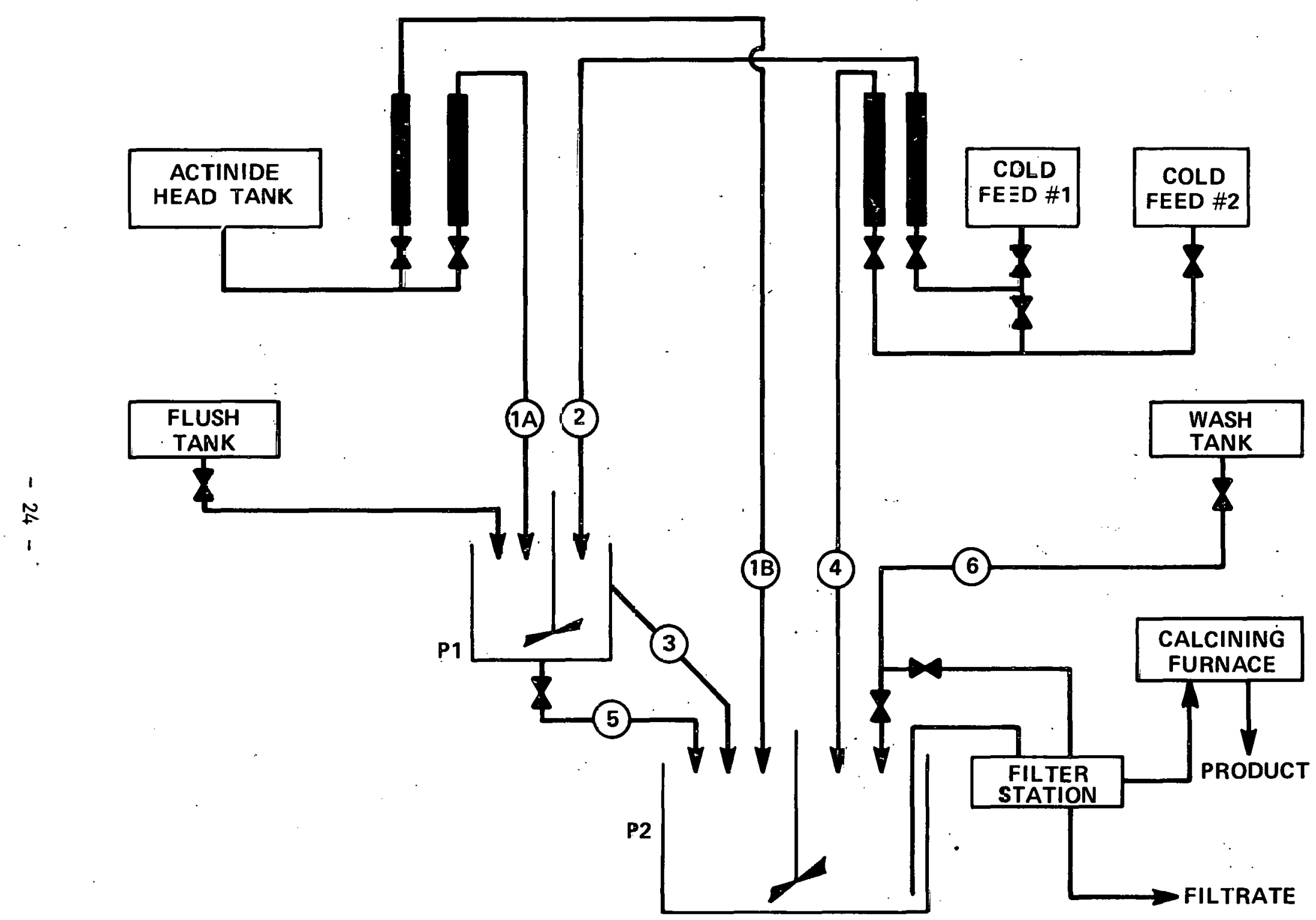

FIGURR 2. Two-stage Precipitation Syatem 


\section{APPENDIX 1. DETERMINING FLOW RATIOS FOR THE SEMI-CONTINUOUS}

\section{PRECIPITATION SYSTEM}

\section{Flow Ratio for the First Stage Precipitator}

The stream designations for the two-stage semi-continuous precipitation are given in Figure 1. The flow ratio for the first stage precipitator is determined as the ratio of the flow rate of the oxalic acid stream to the flow rate of the actinide stream. Thus the streams can be adjusted for any residence time or throughput rate. The flow ratio can be determined by substituting into the following design equations:

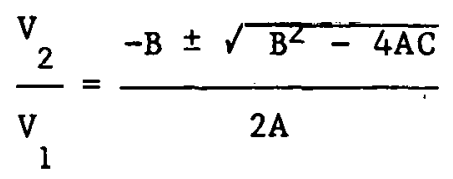

where

$$
\begin{aligned}
& A=\left[\mathrm{H}_{2} \mathrm{C}_{2} \mathrm{O}_{4}\right]_{2}+2[\mathrm{~Np}]_{3}-16 \mathrm{R}_{\mathrm{S} 1}[\mathrm{~Np}]_{3}{ }^{2} \\
& B=\left[\mathrm{H}_{2} \mathrm{C}_{2} \mathrm{O}_{4}\right]_{2}+4[\mathrm{~Np}]_{3}-2[\mathrm{~Np}]_{1} \\
& \mathrm{C}=-2\left([\mathrm{~Np}]_{1}-[\mathrm{Np}]_{3}\right)+\mathrm{R}_{\mathrm{S}_{1}}\left(\left[\mathrm{HNO}_{3}\right]_{1}+4\left([\mathrm{~Np}]_{1}-[\mathrm{Np}]_{3}\right)^{2}\right.
\end{aligned}
$$

$[\mathrm{Np}]_{1} \quad=$ Neptunium feed concentration in stream $\mathbb{N}_{1}$

$\left[\mathrm{HNO}_{3}\right]_{1}=$ Nitric acid concentration in the neptunium feed

$\left[\mathrm{H}_{2} \mathrm{C}_{2} \mathrm{O}_{4}\right]_{2}=$ oxalic acid feed concentration to the first stage precipitator

$[\mathrm{Np}]_{3} \quad=$ Unprecipitated neptunium concentration in the overflow line

$\left[\mathrm{H}_{2} \mathrm{C}_{2} \mathrm{O}_{4}\right]_{3}=0 x a 1$ ic acid concentration in the overflow stream

$\left[\mathrm{HNO}_{3}\right]_{3}=$ Nitric acid concentration in the overflow stream

$\mathbf{R}_{\mathrm{S}} \quad=$ Ratio of oxalic acid concentration to the concentration of nitric acid squared. This is the free oxalate ion concentration.

$[\mathrm{NP}]_{4} \quad=$ Unprecipitated neptunium concentration in the second stage precipitator. This may be a close to the equilibrium solubility value.

$\left[\mathrm{H}_{2} \mathrm{C}_{2} \mathrm{O}_{4}\right]_{4}=$ Oxalic acid concentration to the second stage precipitator. This is the adjustment streall. 


\section{Plow Ratio for Adjustment stream}

The flow ratio for the second stage adjustment stream is given as the ratio of the flow rate of the solubility adjustment stream to the flow rate of the actinide. Absolute flow rates may be determined by setting vessel capacity, residence time, or throughput rate. The flow ratio for the second stage adjustment stream $c$ an be determined by substituting in the following design equations:

$$
\frac{4}{V}=\frac{-B \pm \sqrt{B^{2}-4 A C}}{2 A}
$$

where

$$
\begin{aligned}
A & =\left(\left[\mathrm{H}_{2} \mathrm{C}_{2} \mathrm{O}_{4}\right]_{4}+2[\mathrm{~Np}]_{4}\right)-16 \mathrm{R}_{\mathrm{O}_{2}}[\mathrm{~Np}]_{4}^{2} \\
B & =\left(\left[\mathrm{H}_{2} \mathrm{C}_{2} \mathrm{O}_{4}\right]_{3}-2[\mathrm{~Np}]_{3}=4[\mathrm{~Np}]_{4}=\left[\mathrm{H}_{2} \mathrm{C}_{2} \mathrm{O}_{4}\right]_{4}\right) \\
C & =\left(\left[\mathrm{H}_{2} \mathrm{C}_{2} \mathrm{O}_{4}\right]_{3}-2[\mathrm{~Np}]_{3}+2[\mathrm{~Np}]_{4}\right) \\
& -R_{\mathrm{S}_{2}}\left(\left[\mathrm{HNO}_{3}\right]_{3}+4[\mathrm{NP}]_{3}-4[\mathrm{~Np}]_{4}\right)^{2}
\end{aligned}
$$

and

$$
v_{3}=v_{1}\left(1+v_{2} / v_{1}\right)
$$




\section{Experimental Designs}

Two-level factorial experimental: designs ${ }^{2}$ permit estimation of the effects of several factors simultaneously. This is accomplished by making experimental runs at all combinations of "p" factors, with " 2 " levels per factor. These two-level factorial experiments are easy to design and analyze, are readily adaptable to both continuous and discrete factors, and provide adequate prediction models for factor relationships that have no strong curvature (maximum or minimum). in the experimental region. For continuous variables, : the higher value is coded "+" and the lower value coded "-". The coding for the sixteen run fractional factorial screening design used in the neptunium (IV) oxalate precipitation experiments is given: in Table 2 .

Use of these designs permits estimation of factor effects more precisely than a one-at-a-time testing because of the hidden replication included. Systematic error is kept. to a minimum by replication of design points and randonization of the trails before running:

If a computed factor effect is larger in absolute value than the "minimum significant factor effect," the experimenter can safely conclude that the true effect is nonzero.

Ihe computed tactor effects represent. the difference between response at the high and low levels of the factor. If the factor is divided by the difference of the high and low levels of the factors, the result will be the change in the response for a unit change in the factor.

The model underlying the two-level factorial is of the form

$$
\begin{aligned}
y= & a_{0}+a_{1} x_{1}+a_{2} x_{2}+\ldots a_{p} x_{p} \\
& +a_{12} x_{1} x_{2}+a_{13} x_{1} x_{3}+\ldots+a_{p-1, p} x_{p}-x_{p} \\
& + \text { higher order interactions }
\end{aligned}
$$

where

$y=$ predicted response for: particle size distributions, plating in the precipitators, and extent of precipitation in the first stage precipitator. 


$$
\begin{aligned}
& x_{j}=(\text { factor level }-(H i+L O) / 2)(H i-L O) / 2 \\
& a_{j}=\left(\text { factor effect for } x_{j}\right) / 2 \\
& a_{i j}=\left(\text { interaction effect for } x_{i}, x_{j}\right) / 2
\end{aligned}
$$

The fractional factorial screening design used in the neptunium (IV) oxalate precipitation experiments can be viewed as an estimate of the constant and linear terms of this general polynomial model of the precipitation system. The analysis of this type of screening design is simply multivariable linear regression.

\section{Interpretation of the Screening Design Analysis}

Thre computod fartar effects are che cuelficienta of a linaar uultivailablc modol. If the sign of the computed faccor ellect is negative for a given response: variable, the response decreases as the variable increases. In other words the response and the variable are inversely related. If the computed factor effect is positive, the response and the variable are directly related.

The magnitude of the computed factor effect compared with the "minimum factor effect" determines the level of significance of the variable at a certain level of confidence. Thus, the analysis produces a relative ordering of significance among the variables. The results from screening designs are often used to design further experiments. 
DP-1658

\section{DISTRIBUTION}

Copy

1-3 E. L. Bowser, DOE-SR

4-40 SRL File

41-205 DOE-TIC (for distribution under TID-4500, Category UC-4)

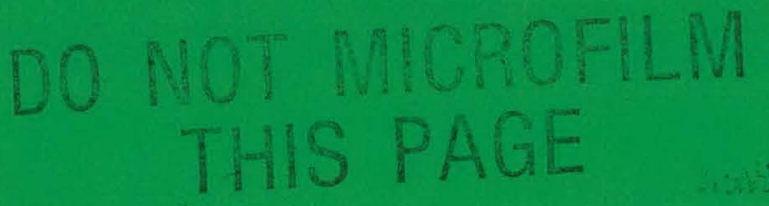

